\title{
THE TAVEUNI EARTHQUAKE FIJI ON 17 NOVEMBER 1979
}

\author{
A.W. Paterson* R.L. Williams**
}

\begin{abstract}
Following the 17th November 1979 Taveuni earthquake, the authors were sent by the Fiji Government to inspect earthquake damage. The damage was assessed at $\$ 0.75 \mathrm{~m}$. This paper is based on their reports and makes recommendations relevant to Pacific Island construction.
\end{abstract}

\section{INTRODUCTION:}

The main shock was reported by the United States Geological survey as -

Time:

15.2126 .4 on 16 th November 1979 Universal Time (3.2lam on 17th November 1979 local time).

Magnitude Ritcher $6.3 \mathrm{MB} 6.9 \mathrm{MSZ}$

Location $\quad 16.512$ S $179.923 \mathrm{E}$

Depth Shallow $33 \mathrm{~km}$ or less

Observations by the Fiji Ministry of Lands and Mineral Resources on the after shocks using portable equipment indicate an epicentre as shown on Figure 1 . The epicentre appears to lie below a 600 metre deep channel between Rabi and the north western tip of Taveuni. The local geology is principally of young volcanic origin.

Fiji is seismically moderately active. Recent earthquakes are shown in Figure 2. It should be noted that this earthquake was the strongest felt since the Suva earthquake (R6.75 of 14th september 1953). Other recent earthquakes causing damage in the Suva area were R6.3 5th June 1961 and R4.5 17th December 1975. A report on recent crustal movement has been prepared by $K$. Berryman, New Zealand Geological Survey D.S.I.R., Wellington this year under the N.Z. Ministry of Foreign Affairs Bilateral Aid Programme.

The main shock was of short duration (most reports indicate only 15 seconds of felt motion). The motion was generally felt as a strong, but steady rolling, motion from the N.W. Numerous aftershocks were felt but these died down quickly. None were felt after 7 weeks but renewed activity was felt in April and May 1980.

* Principal Engineer, Structures, Public Works Department, Suva.

* * District Structural Engineer, Ministry of Works \& Development, Hamilton.
The ground motion in the Matei region was severe particularly on exposed ridges. Strong motion causing significant damage occurred for about half the length of the island and in the Buca Bay area. Figure 1 shows Modified Mercalli intensities assigned by the authors. Structural damage was not as extensive as one might have expected due to a number of factors i.e.

1. The short duration.

2. The relatively smooth rolling motion.

3. The low population density. (Taveuni itself only has a population of about $8,000)$.

4. The low number of buildings built in heavy masonry construction.

The timber construction most commonly used in this area of of a good standard becuase of the hurricane risk.

No loss of life or injuries were reported.

In contrast to the low damage occurring ground effects were quite significant and oddurred throughout the area the author's assigned MM7.

\section{GENERAL OBSERVATIONS :}

\section{General Topography -}

The island of Taveuni is some $40 \mathrm{~km}$ long by $15 \mathrm{~km}$ wide. It is steep rugged country composed largely of scoria ash and volcanic debris rising to $1200 \mathrm{~m}$. Only the lower hills are farmed, mainly with coconut plantations. Coral formation is limited by the steeply shelving sea floor.

Soil Effects -

No particular movement has been directly attributed to faulting but settlement of road and other filling was extensive within the area indicated as MM7. Damage to buried services and earthenware drains in this area was also extensive. Slips blocked roads in many places and boulders 


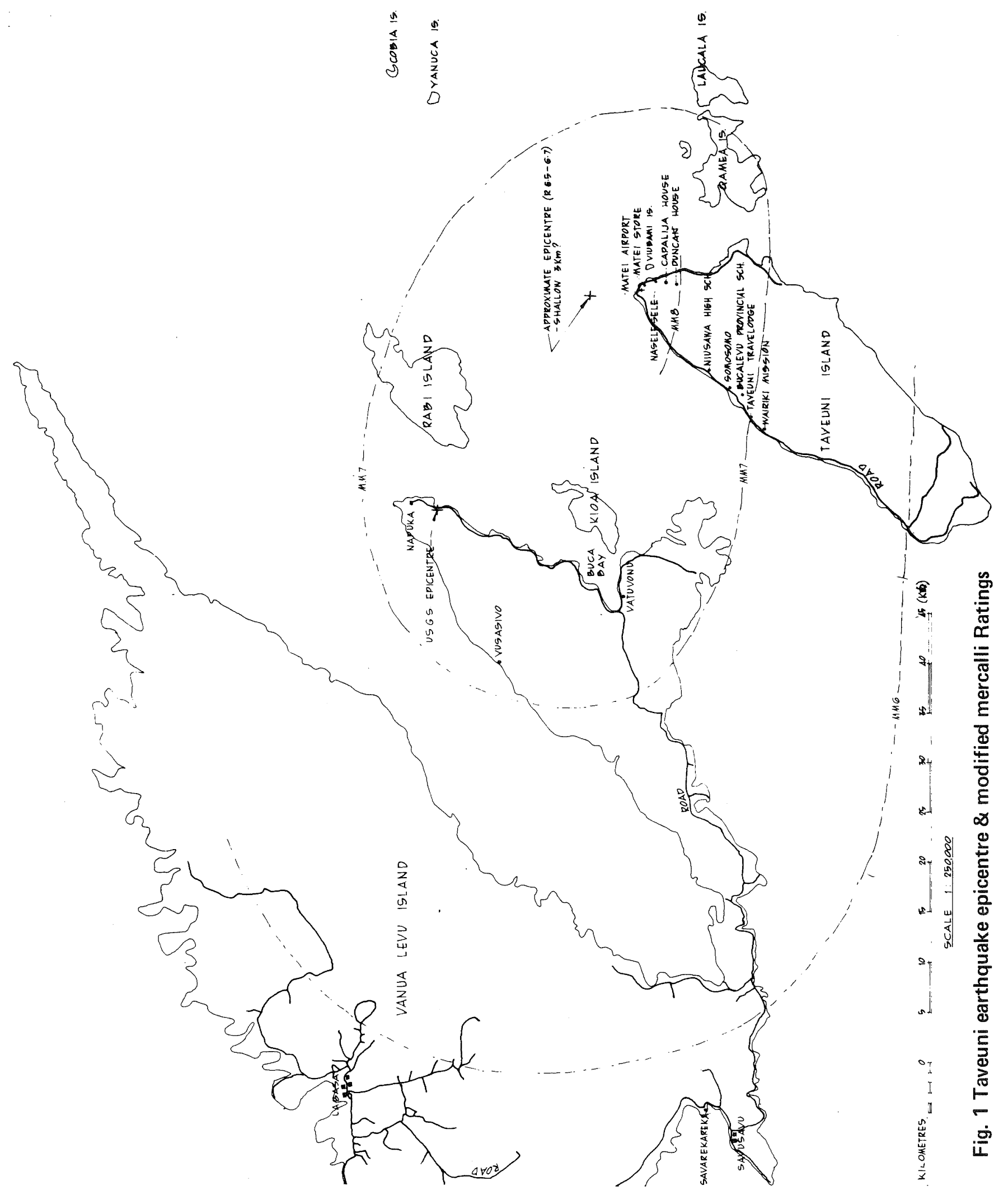




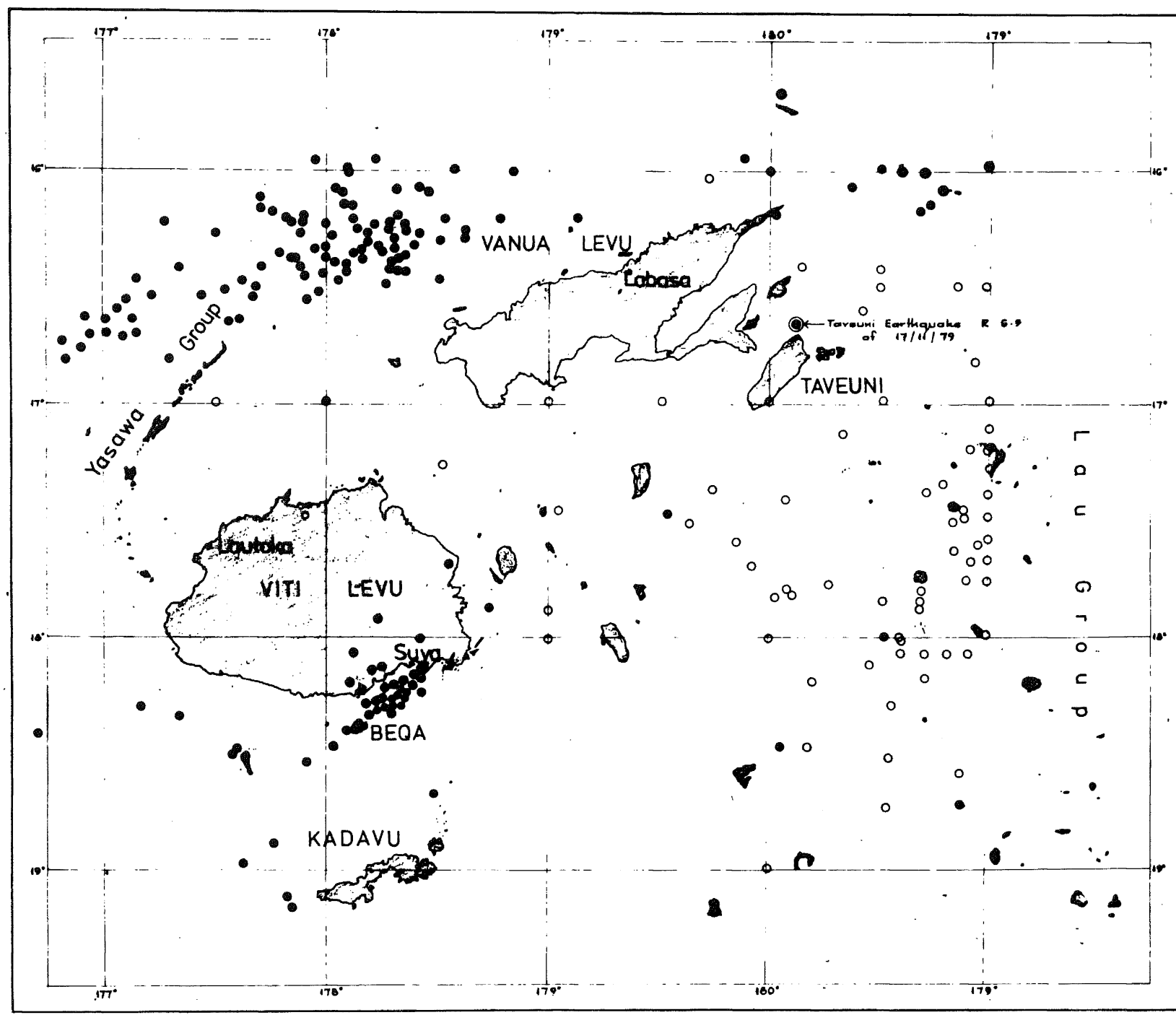

Legend

Recorded Shallow Epicentres - $<33 \mathrm{~km}$

Earthquake Recorded Epicentres - Fiji

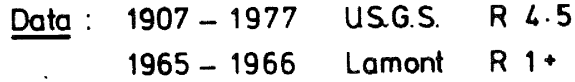

- Recorded Deep Epicentres

July 1976 - June $1978 \quad$ M.R.D. All

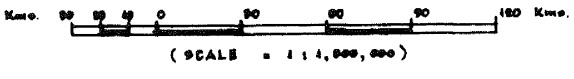

Fig. 2 
rolled down hills (figure 3), rocks over 100 tons had fallen in some islands. Most of the seaward face of the island of Viubani, off Matei slipped away (figure 4). Slipping was aggrevated by early heavy rain and slipping was expected to continue as rain runs into cracks opened up by the earthquake. Slipping is not uncommon in this area because of the loose materials and steep nature of the hillsides.

\section{Blowholes -}

Blowholes occurred in a number of places near the epicentre. Noteable cases were at Qamea Island where water gushed out leaving holes up to 5 metres deep and flooding the playing field up to ankle depth. The area was just above sea level. Similar effects occurred as far away as Vusasivo on Vanua Levu where fine sand was ejected. The authors observed similar deep holes at Wairiki and also on the beach opposite Matei store at Naselesele where sand and scoria had been ejected (figure 5). These latter holes were at approximately half tide and were about one metre across. They were gushing several hundred gallons a minute to clear, slightly salty water 6 days after the earthquake. It appeared that liquefaction had opened up fissures in the ground. However the water may be from natural aquifers supplemented by water squeezed out by settlement of nearby areas.

A team from the department of Mineral Resources observed fresh sand craters 3 to 4 metres diameter and 3 metres deep in the seabed slightly below the low water mark off Viubani Island.

\section{Tsunami -}

The only report of a tidal wave was just south of Naselesele where debris was found on the road about 1.5 metres above the sea level at the time of the earthquake. Muddy water was reported off Vuibani Island and in 2 places off Qamea Island indicating possible slumping of the coral reef.

\section{BUILDING STRUCTURES:}

\section{Timber Building -}

The majority of these were completely undamaged. Where damage did occur it was to the foundation. At least one building fell off its piles. Many others suffered pile damage. Some timber piles had clearly rotted, the earthquake causing final collapse. A surprisingly large number of concrete piles completely shattered (figure 6). The concrete failed in a brittle manner; the cement not bonding to the large aggregate. This appeared to be a combination of low cement ratio and dirty aggregate. The central reinforcing bars showed rusting although the outside of the piles did not indicate unsoundness. Clearly the standard of concrete piles should be upgraded.
Just south east of Naselesele on the Nagasau Estate 2 houses (owned by $\mathrm{Mr}$ Capalija and Mr Duncan) exhibites signs of very severe shaking. Both houses were of substantial construction and about 50 years old and both were on exposed ridges. These houses had timber piles but in both cases many of the piles had been strengthened by concrete pads $500 \mathrm{~mm}$ square at their bases. The severe shaking displaced many of the weaker piles and the stronger piles had visible signs of considerable movement. Concrete rubble floors in bathroom and verandah areas (figure 7) had completely disintegrated and out-houses had been badly damaged. The shaking had thrown all loose furniture over the rooms (figure 8) much of it over-turning and being damaged beyond repair and at least half the contents would have to be written off. Paintings were thrown off walls breaking substantial wire supports. It is estimated accelerations of $0.5 \mathrm{~g}$ would be required to cause this type of damage.

\section{Reinforced Concrete Buildings -}

Very few buildings were built in this material. Only in 2 cases did significant damage occur. The S.D.A. Mission School suffered very serious damage to the 5 classroom reinforced concrete and masonry building (figure 9). Extensive cracking and spalling occurred throughout the building. The building occurred mainly due to poor concrete. The concrete had an excessive sand content and low cement content which has mainly been absorbed in coating the sand. This left a mix with insufficient cement to be impervious and counteract the effect of the salts. Extensive rusting of the bars has occurred further weakening the construction.

Since the earthquake immediate action has been taken by the Mission and within one month they had removed all walls and cast new foundations and floor slabs in high quality reinforced cement. They have replaced all walls with timber construction. The original roof was propped during reconstruction and has now been firmly bolted down. It was interesting to note that a blockwork 2 classroom block on the same site was well constructed and had only hairline cracking as a result of the earthquake.

The St. Andrews Anglican Secondary School, Labasa suffered damage to its Domestic Science and Woodwork block similar to that in the Vatuvonu S.D.A. School, but damage was less serious and demolition was not recommended.

\section{Blockwork -}

Blockwork was not extensively used in the area but probably a quarter of these building in the Taveuni and Buca Bay areas showed some signs of damage. Damage at the Niusawa Methodist High School occurred in several buildings. In the classroom block the non structural partition walls 


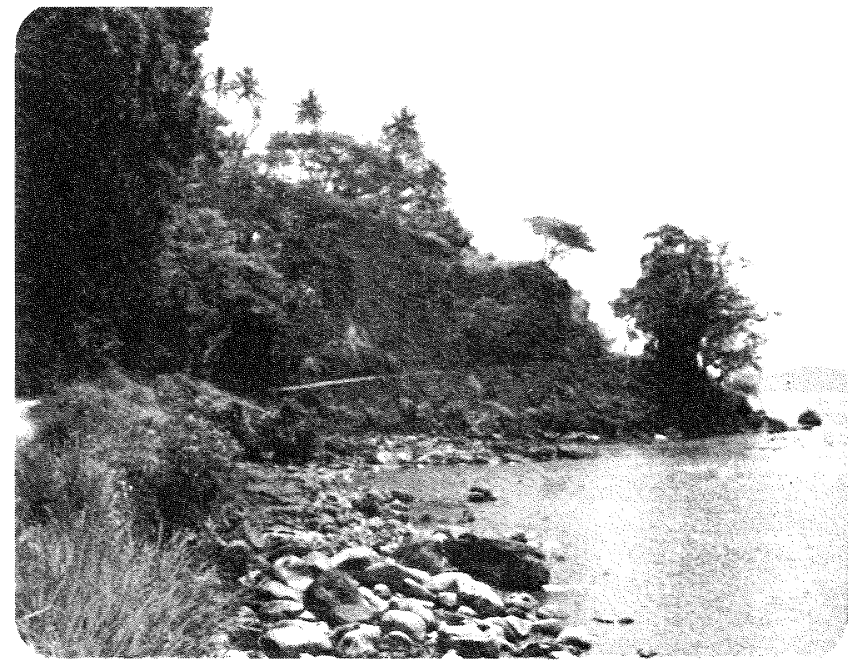

Fig. 3 Slipping South of Matei

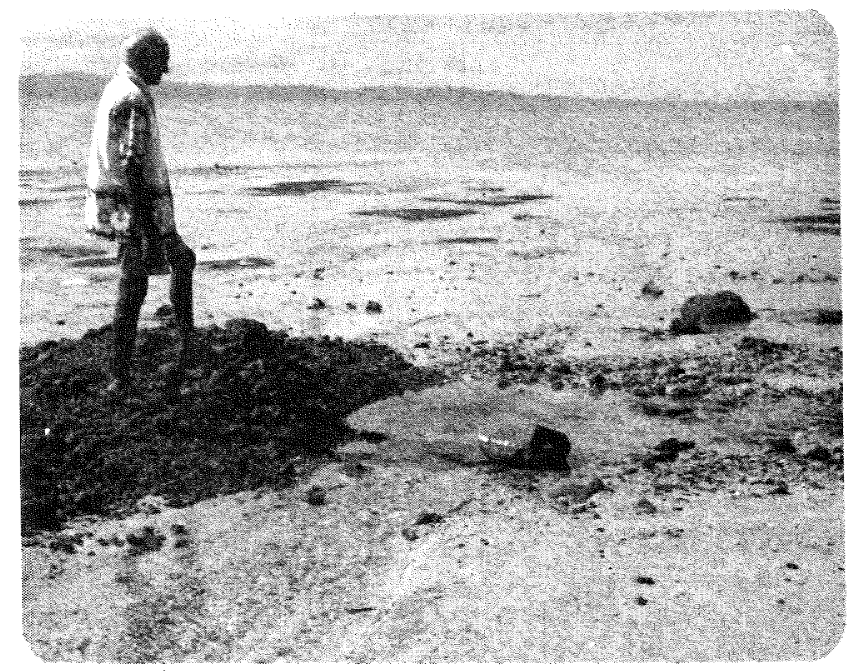

Fig. 5 Blowholes on Beach Naselesele

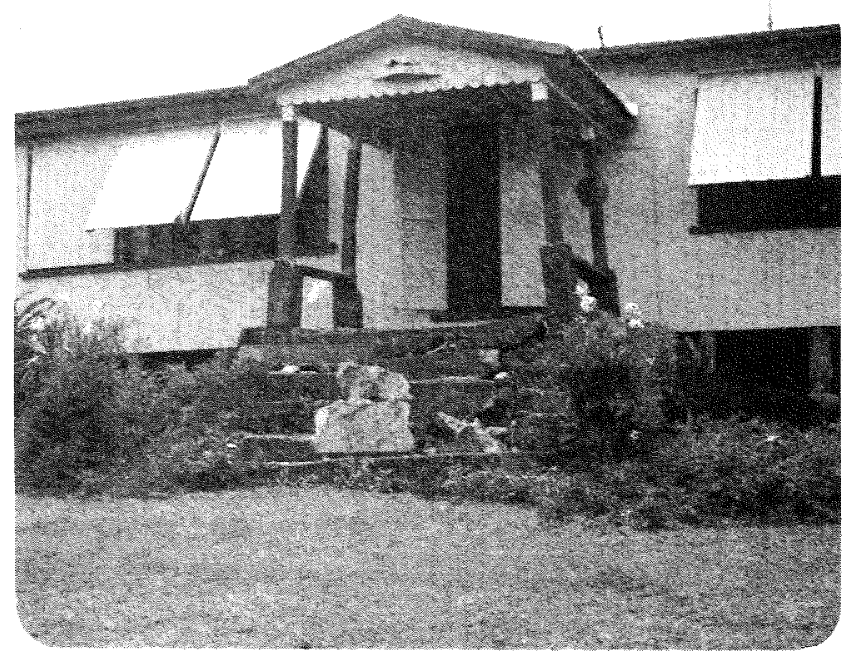

Fig. 7 Broken terrace, Mr Duncan's House, Naselesele

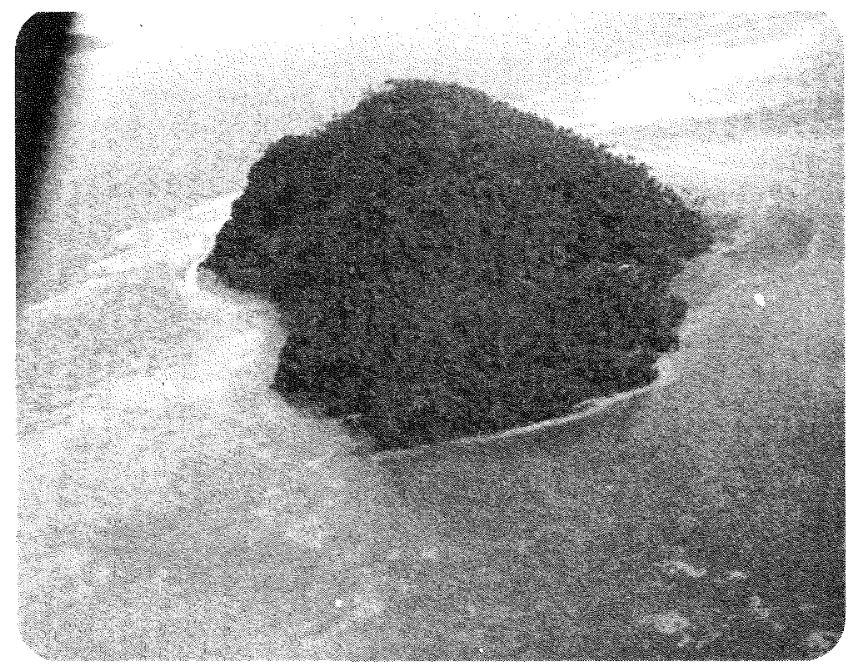

Fig. 4 Slipping on Viubani Island

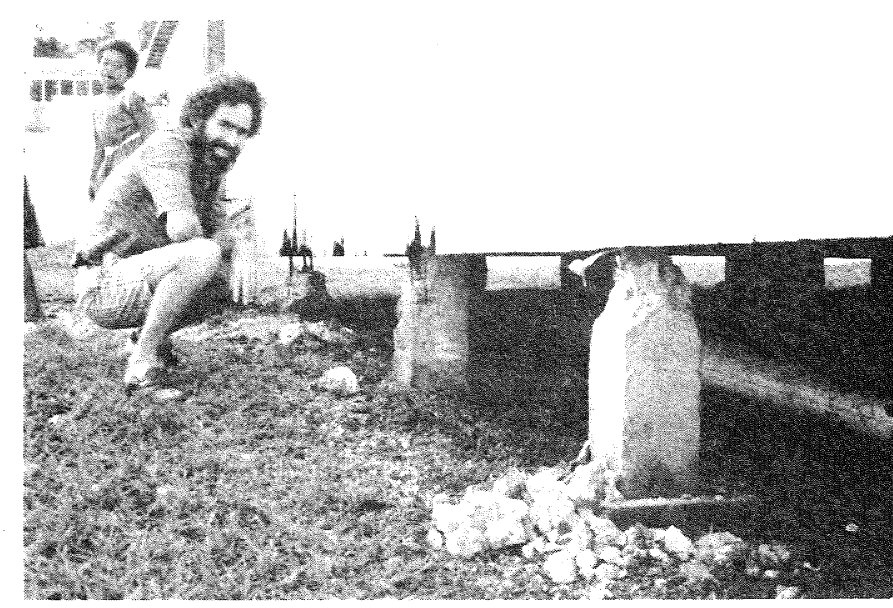

Fig 6. Damage to concrete House piles Niusawa High School

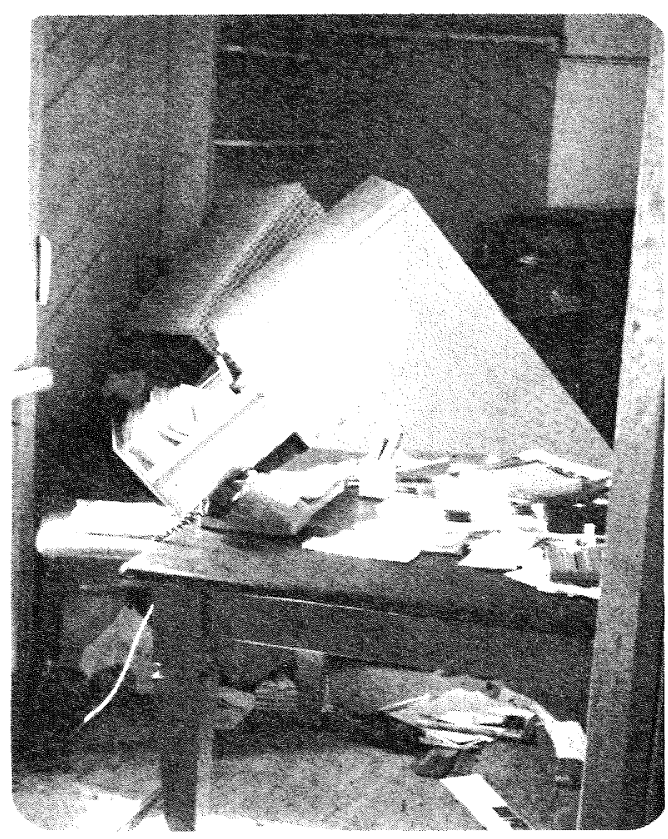

Fig. 8 Furniture overturned, Mr Capilija's House, Naselesele 


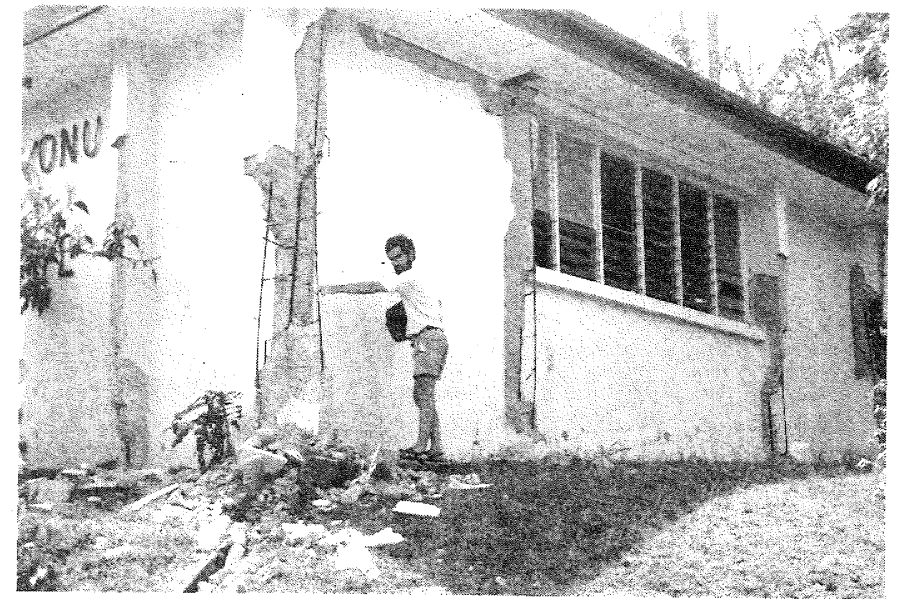

Fig. 95 classroom block Vatuvonu School

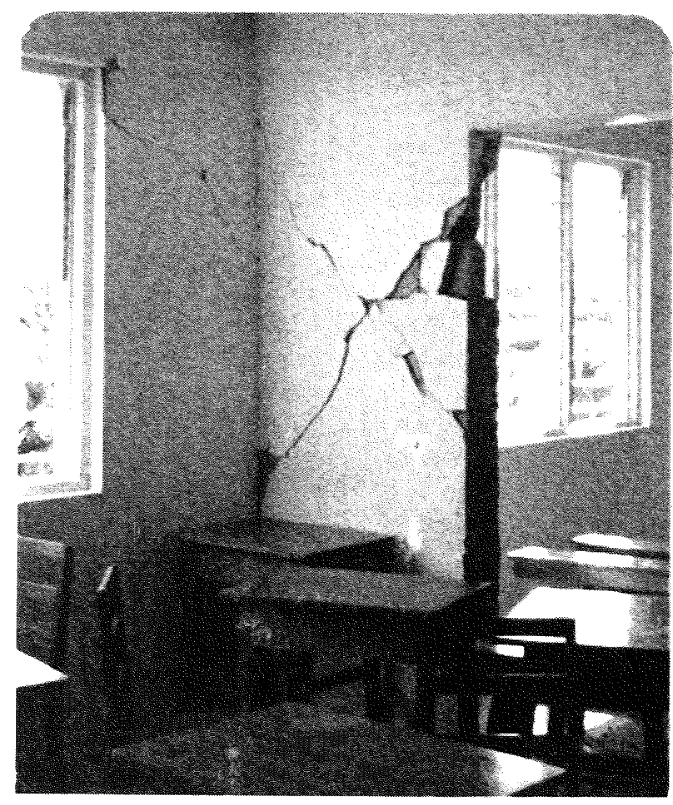

Fig. 11 Damaged Blockwork Bucalevu School

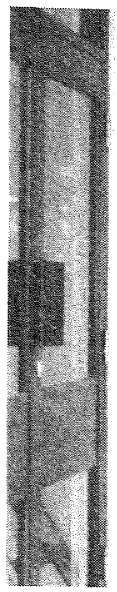

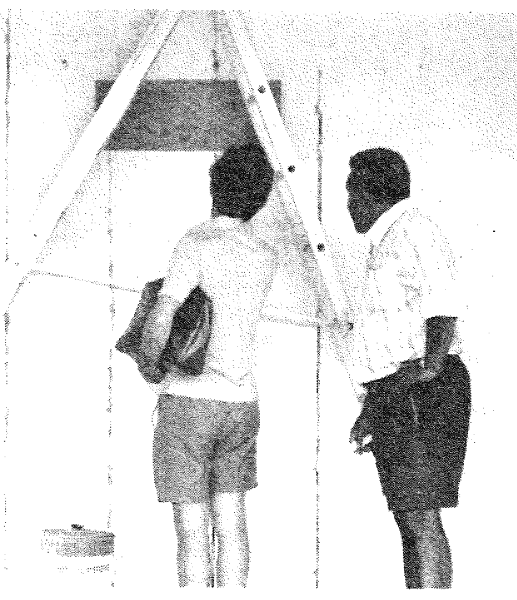

Fig. 13 Failure of stackbonded blockwork - National Bank of Fiji, Labasa

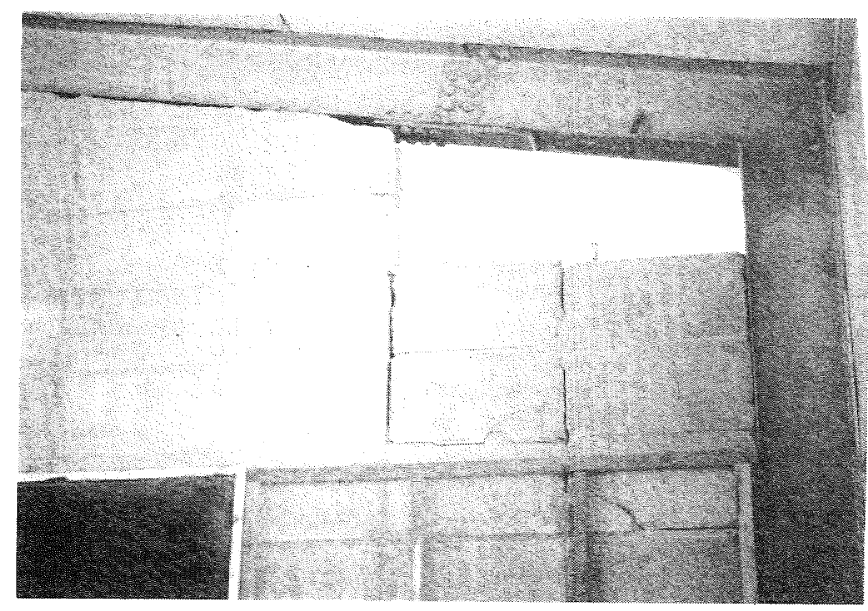

Fig. 10 Damaged blockwork partitions - Niusawa High School

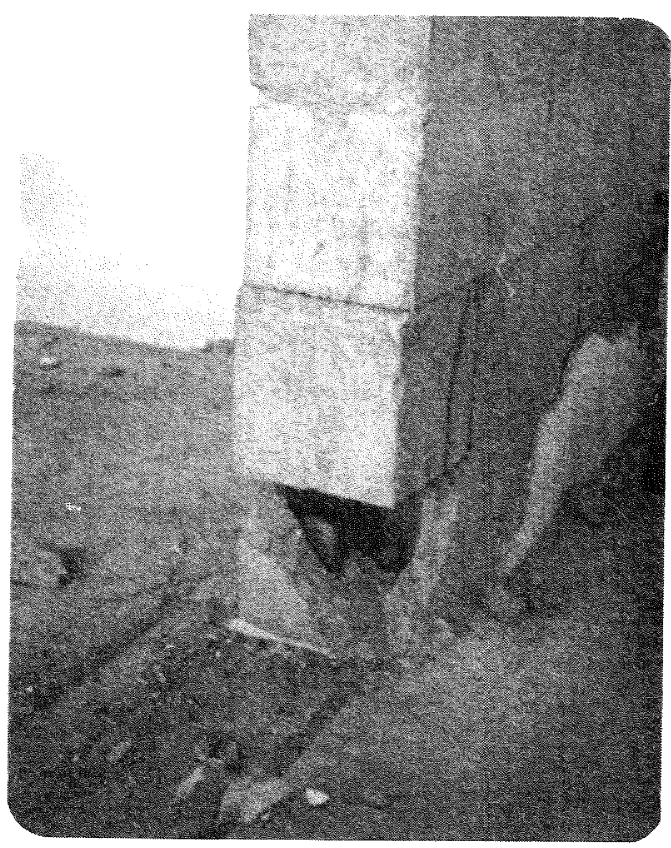

Fig. 12 Ungrouted reinforcement Bucalevu School

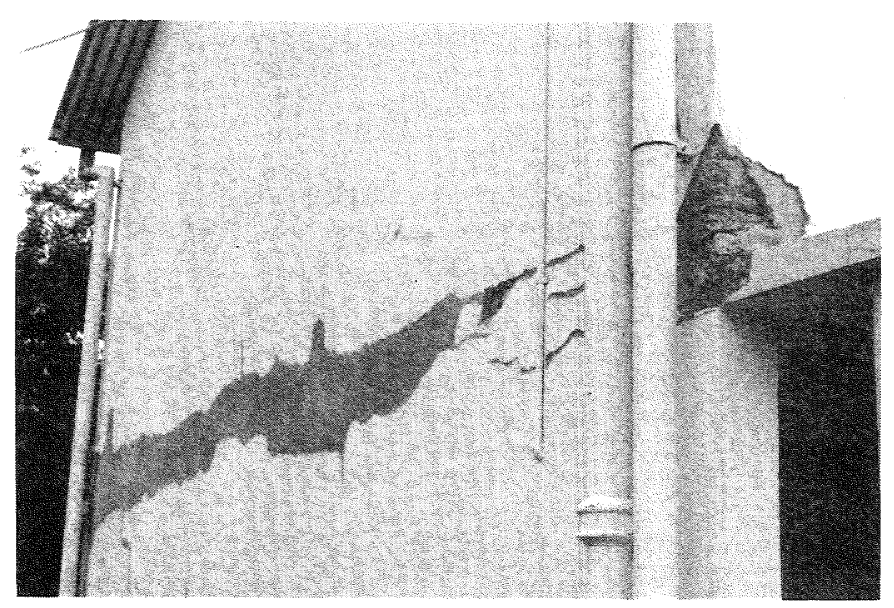


had separated from the steel portal frame (figure 10), locating bolts were torn out and stack bonding failed. This building was $\mathrm{x}$-braced in the other direction.

At Bucalevu Junior/Secondary School the interior wing walls between 2 classrooms showed serious cracking. One wall showed shear cracking (figure 11) while others failed due to inadequate grouting at the base (figure 12).

Damage that occurred remote from the epicentre in the new National Bank of Fiji in Labasa. This building had not even been opened yet it suffered damage to several of its stackbonded blockwalls (figure 13).

Damage also occurred at a 2 storey standard government maisonette at Labasa (figure 14). This was apparently due to a shear friction failure that occurred on an unnecessary damproof course that had been added at first storey height.

Rubble Concrete Construction -

Buildings of this construction were built by early missionaries and settlers about eighty years ago. The construction generally consists of mass concrete, usually $600 \mathrm{~mm}$ thick, with large stones and no reinforcement. The cement used was, in many cases, made locally from finely ground and burnt coral.

Most of these buildings suffered damage. A summary of the damage is as follows -

Wairiki Catholic Mission - Extensive damage to the 2 storey mission house. This is a fine old colonial style building built by early French missionaries in about 1900. The authors have proposed that all the top storey walls and gables be removed. A substantial reinforced concrete bond beam $600 \mathrm{~mm}$ wide should be constructed on top of the existing lower floor walls prior to reconstruction of the upper floor walls in timber framing and weatherboards. This proposal reduces much of the weight of the structure yet allows the basic form to be retained within the limited financial resources available. At the same mission a dormitory and the main church were also damaged. One wall of the dormitory is to be replaced in reinforced concrete in order to give the building a limited life. The church is to have its tower strengthened by tie rods and an internal skin of reinforced concrete.

Napuka Catholic Mission - The main church, the priests house, convent, dormitory and a workshop classroom were all condemned as irrepairable. All were constructed in rubble concrete. church (figure 15) was damaged by an earthquake in 1921 and was subsequently strengthened by reinforced concrete bands and piers both inside and out. These bands, visible in the photograph do not appear to have greatly improved the earthquake resistance but do appear to have saved the building from total collapse.

Other damage to this type of construction occurred at Savarekareka Catholic Mission House and Somosomo Methodist Church (see figure 16).

\section{Reservoirs -}

One 85,000 litre reservoir at Naselesele composed of frames, concrete staves and external tension rods suffered minor damage to its roof by yield line cracking of its insitu reinforced concrete roof. A large number of conventional corrugated iron watertanks were lost.

\section{Bridges -}

Many bridge approaches settled up to $450 \mathrm{~mm}$ but only the Buca Bay bridge showed any evidence of structural damage. Most bridges are one lane simple span structures with steel beams and usually concrete decks. Spans are 9 to 12 metres and beams are bolted to the abutment (temperature movement is minimal in $\mathrm{Fiji}$ ). In the case of the Buca Bay bridge ( 6 spans of 12 metres with a concrete deck) the abutment had moved in about $15 \mathrm{~mm}$ causing minor cracking on impact with the deck. The handrails went into compression and caused a shearing failure of the concrete end blocks mounted on the abutments.

\section{Stores -}

The earthquake caused losses of stored goods throughout the region. Potentially the most serious was loss of medical supplies at the Somosomo hospital. New supplies were flown in once roads were cleared and the airstrip reopened (it was closed due to settlement cracking on part of the runway).

\section{CONCLUSIONS AND RECOMMENDATIONS:}

The recent earthquakes are a warning the Fiji lies in a region of at least, moderate seismicity. It is fortunate that this earthquake occurred in a region of low population and with little modern development. If a similar earthquake had occurred near suva it could have resulted in a multi-million dollar disaster that would take years to recover from.

This earthquake did not test modern Fiji construction but it was apparent that blockwork was particularly vulnerable to damage due to poor design and construction. The authors recommend all cells filled construction with $12 \mathrm{~mm}$ reinforcement at $600 \mathrm{~mm}$ centres both ways. Stack bonding of mortar joints is particularly vulnerable to damage and should be avoided. Grouting was particularly poor. A free flowing mix should be used and well compacted by rodding. Only deformed steel should be used. Laps should be at least 40 diameters because of poor bonding of grout to steel.

Timber construction was rarely damaged except for a few foundation failures. The cement content of concrete piles should be 
braced by short concrete walls at the corners or similar. For fijian conditions where timber is easily obtainable it would appear this may be a more suitable medium for many domestic buildings rather than the currently more fashionable 'maintenance free' but vulnerable heavy concrete masonry.

Rubble concrete was extensively damaged and any building of this type must be considered an earthquake risk.

Concrete construction failed due to low cement contents together with oversanded mixes. The combination of low cement content unwashed coral beach sand and poor compaction are all factors which contribute to the corrosion of reinforcement.

Ground effects were quite marked. From damage reports it was clear that the intensity of shaking was greater on ridges and on filled ground. Clearly construction should be kept away from unfavourable ground conditions wherever possible.

Outside Suva building regulations are principally for health protection. It is clear that all major structures should be designed to a uniform standard of design and construction. New Zealand based codes would appear to be the most appropriate for earthquake construction and the authors recommend that NZS 4203 'Code of Practice for General Structural Design and Design Loadings for Buildings' be adopted. Earthquake loadings should not be less than those appropriate for Zone B.

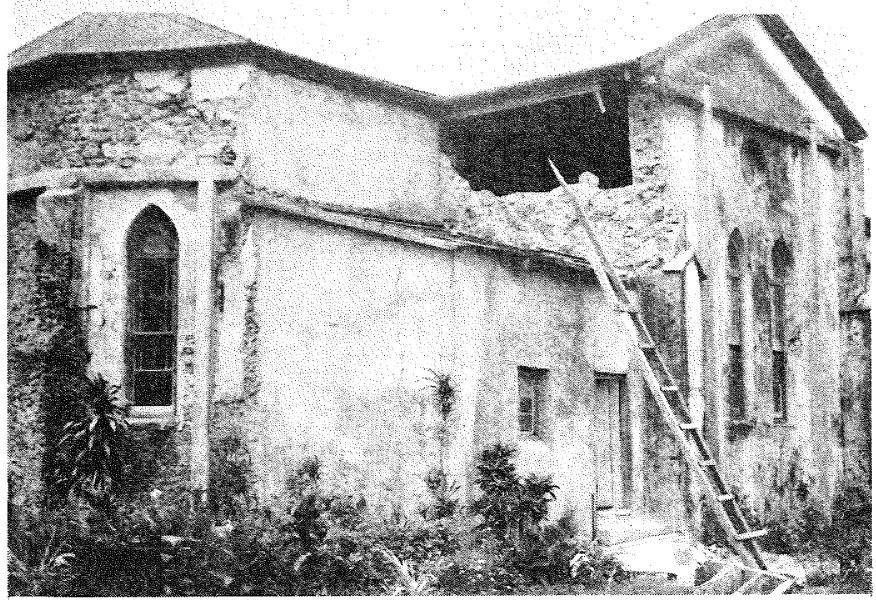

Fig. 15 Failure of rubble concrete - Napuka Catholic Church (Note Strengthening)
Much of the minor building construction in $\mathrm{Fiji}$ relies on the experience persons have gained from working on major construction for the PWD or Army. It is important that the example set is of the highest standard. Minor building codes should be in the form of standard designs and include pictorial literature.

It seems that because the value of damage from this earthquake $(\$ 750,000)$ was not great and because it was remote from Suva the lessons to be learnt may go unheeded despite the higher seismic risk of Suva itself.

\section{ACKNOWLEDGEMENTS:}

To the Secretary of Works - P.W.D., Fiji for the opportunity to visit the damaged areas and to the New Zealand Government for whom the second author was carrying out a Bilateral Aid Project for training P.W.D. Fiji staff in earthquake engineering at the time of the earthquake.

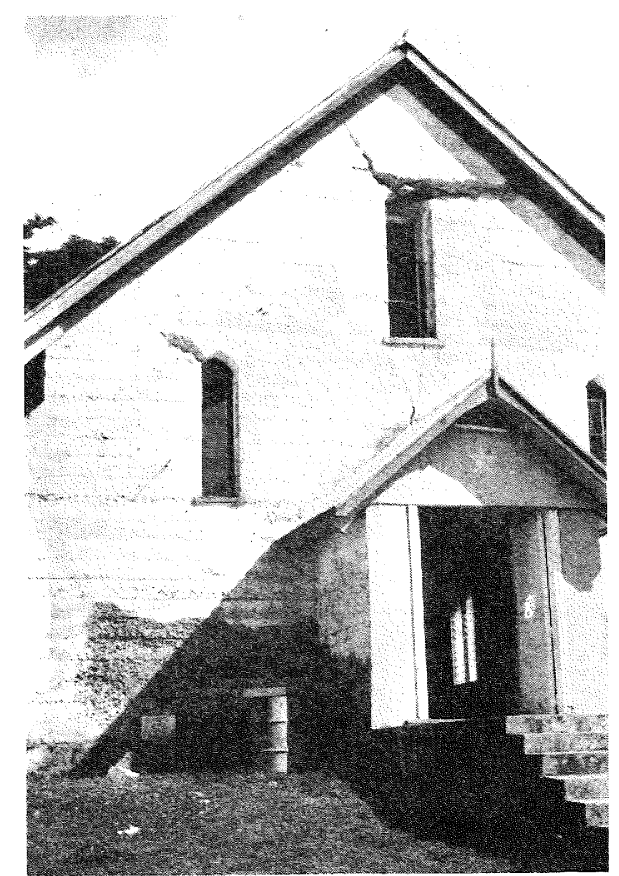

Fig. 16 Failure of rubble concrete - Somosomo Methodist Church 